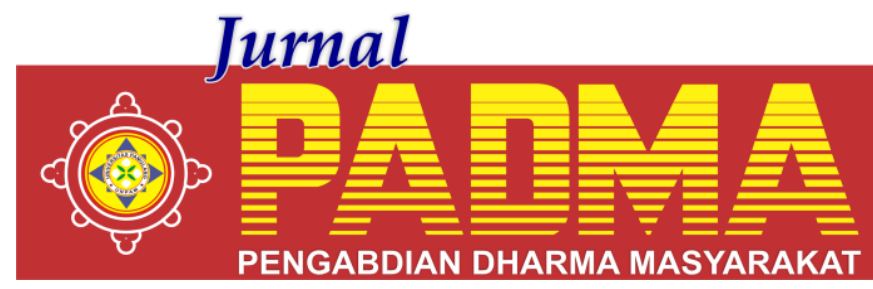

VOLUME 1, NOMOR 2, APRIL 2021

\title{
PERAN PEMUDA KREATIF DALAM PEMANFAATAN MEDIA SOSIAL SEBAGAI SARANA PENINGKATAN PEREKONOMIAN DI ERA PANDEMI
}

\author{
${ }^{1 *}$ Alya Santika, ${ }^{2}$ Anisa Puji Lestari, ${ }^{3}$ Lisa Kumara, ${ }^{4}$ Muhammad Jajang, ${ }^{5}$ Nabila Khairunnisa \\ Universitas Pamulang, Tangerang Selatan, Banten, Indonesia \\ *alyasan880@gmail.com
}

\begin{abstract}
Abstrak
Kewirausahaan adalah sebuah proses dalam menciptakan sesuatu yang baru, dimana proses dalam pengerjaannya dilakukan dengan kreatif dan penuh dengan inovasi. Dengan adanya kewirausahaan di masa pandemi covid 19 dapat membuka lapangan pekerjaan untuk orang lain, menciptakan jaringan bisnis yang baru yang bisa menyerap banyak tenaga kerja di daerah asal, meningkatkan kesejahteraan kehidupan diri sendiri serta masyarakat sekitar dari usaha yang dijalankannya, serta kewirausahaan dapat menularkan dan mengembangkan semangat berwirausaha pada orang lain. Tujuan Pengabdian Kepada Masyarakat Mahasiswa ini adalah untuk memberikan pengetahuan kepada pemuda Karang Taruna Dharma Temaja Sumurugul, Kecamatan Wanayasa Kabupaten Purwakarta Jawa Barat pentingnya kreatifitas dalam memanfaatkan media sosial sehingga dapat menumbuhkan jiwa kerwirausahaan di masa pandemi covid 19 guna meningkatkan perekonomian. Adapun metode pelaksanaan kegiatan ini adalah melalui video conference via google meet dengan memberikan materi serta diskusi pentingnya peran pemuda yang kreatif di era pandemi. Hasil dari kegiatan ini para peserta menjadi lebih mengerti dan memahami bagaimana menjadi pemuda yang kreatif dalam memanfaatkan sosial media sebagai salah sarana untuk meningkatkan perekonomian di era pandemi sehingga kedepannya diharapkan Pemuda Karang Taruna Dharma Temaja Sumurugul dapat memanfaatkan media sosial dengan maksimal dan memunculkan ide serta kreatifitas guna mendorong perekonomian daerah sekitar.
\end{abstract}

Kata Kunci : Kewirausahaan, Media Sosial, Pandemi Covid 19

\begin{abstract}
Entrepreneurship is a process in creating something new, where the process is done creatively and full of innovation. With entrepreneurship during the covid 19 pandemic new jobs can be opened for other people, create new business networks that can absorb a lot of workforce in the area of origin, improve the welfare of themselves and the surrounding community from the business they run, and entrepreneurship can transmit and develop entrepreneurial spirit in others. The purpose of this Student Community Service is to provide knowledge to youth of Karang Taruna Dharma Temaja Sumurugul, Wanayasa Subdistrict, Purwakarta Regency, West Java, the importance of creativity in utilizing social media so that it can foster an entrepreneurial spirit during the Covid-19 pandemic to improve the economy. The method of implementing this activity is through a video conference via Google meet by providing material and discussion of the importance of the role of creative youth in the pandemic era. The results of this activity the participants became more aware and understood how to become creative youths in utilizing social media as a means to improve the economy in the pandemic era so that in the future it is hoped that the Youth of Karang Taruna Dharma Temaja Sumurugul can make maximum use of social media and come up with ideas and creativity to use it. encourage the economy of the surrounding area.
\end{abstract}

Keywords: Entrepreneurship, Social Media, Covid 19 Pandemic.

\section{PENDAHULUAN}

Karang Taruna adalah organisasi kepemudaan di Indonesia. Karang Taruna merupakan wadah pengembangan generasi muda nonpartisan, yang tumbuh atas dasar kesadaran dan rasa tanggung jawab sosial dari, oleh dan untuk masyarakat khususnya generasi muda di wilayah Desa / Kelurahan atau komunitas sosial sederajat, yang terutama bergerak dibidang kesejahteraan sosial. Sebagai organisasi sosial kepemudaan, karang taruna merupakan wadah pembinaan dan pengembangan serta pemberdayaan dalam upaya mengembangkan kegiatan ekonomis produktif dengan pendayagunaan semua 
potensi yang tersedia dilingkungan baik sumber daya manusia maupun sumber daya alam yang telah ada.

Kewirausahaan adalah sebuah proses dalam menciptakan sesuatu yang baru, dimana proses dalam pengerjaannya dilakukan dengan kreatif dan penuh dengan inovasi. Dengan adanya kewirausahaan di masa pandemi covid 19 dapat membuka lapangan pekerjaan untuk orang lain, menciptakan jaringan bisnis yang baru yang bisa menyerap banyak tenaga kerja di daerah asal, meningkatkan kesejahteraan kehidupan diri sendiri serta masyarakat sekitar dari usaha yang dijalankannya, serta kewirausahaan dapat menularkan dan mengembangkan semangat berwirausaha pada orang lain.

Para pelaku usaha bisa memanfaatkan media sosial yang ada sebagai strategi marketing. Bahkan saat ini, media sosial menjadi cara yang paling ampuh dalam hal mempromosikan produk yang ada. Potensi bisnis yang sangat besar di media sosial tentunya mendorong pelaku usaha untuk semakin meningkatkan kualitas yang ada agar dapat mempromosikannya dengan baik dan menarik konsumen yang akhirnya mendapat pelanggan yang cukup besar untuk melampaui target penjualan. Didalam mempromosikan bisnis di media sosial tentunya membutuhkan strategi komunikasi yang matang agar pasar di media sosial ini tergarap secara efektif dan efisien. Selain kita memiliki akun media sosial yang mempromosikan produk bisnis yang kita produksi, kita juga dapat melibatkan inflluencer untuk dapat memasarkannya di media sosial mereka. Influencer memiliki banyak followers yang percaya dengan apa yang mereka promosikan dan pakai. Strategi ini bisa sangat ampuh jika kita memang memiliki kualitas yang terbaik. Tentu konsumen akan lebih banyak dan percaya dengan produk yang kita produksi.

Kegiatan Pengabdian Kepada Masyarakat bekerja sama dengan Karang Taruna Dharma Temaja yang berlokasi di Desa Sumurugul, Kecamatan Wanayasa, Kabupaten Purwakarta. Indonesia mengonfirmasi kasus pertama infeksi virus corona penyebab Covid-19 pada awal Maret 2020. Hampir seluruh sektor mengalami dampak dari pandemi ini, salah satunya adalah Sektor ekonomi. Pembatasan aktivitas masyarakat berpengaruh pada aktivitas bisnis yang kemudian berimbas pada perekonomian. Pandemi yang masih berlanjut ini ternyata menjadi hambatan bagi para pemuda di desa untuk terus berkarya dan berkembang. Para pemuda karang taruna yang masih terbatas akses untuk mendapatkan informasi dan kurangnya kreatifitas dalam memanfaatkan teknologi membuat mereka mengalami kondisi ekonomi yang semakin turun. Keterbatasan fasilitas dan relasi membuat para pemuda semakin tidak semangat dan malah terlena dengan keadaan yang tercipta. Maka dari itu diperlukan adanya dorongan semangat dan arahan yang nyata agar mereka dapat melihat peluang dengan memafaatkan teknologi lewat media sosial yang sudah tidak asing.

\section{METODE}

Metode Pelaksanaan Pengabdian Masyarakat ini diantaranya : Tahap pertama yaitu Pemberian Materi Pemanfaatan Media Sosial Sebagai Sarana Peningkatan Perekonomian di Era Pandemi. Dalam memberikan materi pemanfaatan media sosial ini, akan dibahas mengenai peran media sosial dalam memasarkan produk, hal ini agar pihak mitra yaitu pemuda anggota karang taruna Dharma Temaja Sumurunggul bisa menyalurkan kreatifitasnya dalam membuka usaha kreatif dan inovatif di masa pandemi covid 19 dan bisa memanfatkan peran media sosial dengan baik untuk memasarkan produk secara online.

Menurut Suryana (2015), untuk memulai usaha baru atau merintis usaha baru, modal utama yang harus ada pertama kali adalah ide, baik itu ide untuk melakukan proses imitasi dan duplikasi, ide untuk melakukan pengembangan atau ide untuk menciptakan sesuatu yang baru dan berbeda. Setelah ada ide, lakukan analisis kelayakan usaha termasuk analisis kekuatan, kelemahan, peluang dan ancaman. Dalam pemberian materi Pemanfaatan Media Sosial Sebagai Sarana Peningkatan Perekonomian di Era Pandemi oleh mahasiswa - mahasiswa menggunakan alat bantu berupa aplikasi google meet dikarenakan kondisi pandemi covid 19 yang masih berlangsung. Oleh sebab itu tim PKM menghindari kerumunan supaya 
dapat membantu memutus rantai penyebaran covid 19. Tahap kedua yaitu : Diskusi dan Tanya Jawab antara peserta kepada tim PKM, kemudian TIM PKM yang merupakan mahasiswa - mahasiswa Prodi Manajemen Universitas Pamulang menanggapi dan menjawab pertanyaan yang diajukan oleh para peserta, pertanyaan yang diajukan seperti : teknik mengambil gambar dan membuat kalimat persuasif untuk menarik minat pelanggan di media sosial dan produk apa saja yang sedang booming saat ini. Solusi yang diberikan kepada anggota karang taruna adalah mengenai cara memanfatkan peluang usaha dengan menggunakan media sosial instagram, facebook, dan whatssApp untuk meningkatkan penjualan dan meluaskan pangsa pasar dari produk yang di jual. Kegiatan Pengabdian Kepada Masyarakat ini dilaksanakan dengan cara menghubungi pihak terkait yaitu Karang Taruna Desa Sumurugul yang kami temukan melalui media sosial Instagram, kemudian kami menawarkan webinar ini dan pihak Karang Taruna menyetujuinya. Setelah itu ditentukan waktu dan bahan-bahan lainnya sampai bisa terlaksana kegiatan webinar melalui Video Conference Google Meet pada tanggal 21 Februari 2021.

\section{HASIL DAN PEMBAHASAN}

Agar masyarakat di desa, para pemuda khususnya bisa terus berkarya dan berkembang di masa pandemik ini, maka hal yang bisa dilakukan adalah terus mempelajari dan mengeksplorasi tentang media sosial agar bisa digunakan secara tepat dan maksimal untuk meningkatkan perekonomian di masa pandemic. Menjadi kreatif dan inovatif harus dilatih agar bisa mengikuti perkembangan zaman yang semakin maju ini. Melalui pemanfaatan media sosial akan menggugah semangat dan menghasilkan banyak ide untuk coba diterapkan di desa, menyadari batasan penggunaan media sosial akan menghindarkan dari penyalahgunaan media sosial itu sendiri. Media sosial apabila dipelajari dengan baik maka produk yang dihasilkan di desa, dan potensi yang muncul di desa bisa terekspos secara luas dan menjadikan desa itu berkembang lebih baik perekonomiannya. Para pemuda berperan penting agar suatu desa bisa lebih cepat berkembang dan meningkat perekonomiannya. Para pemuda harus kuat dan bersemangat serta menjaga kelestarian budaya di desa.

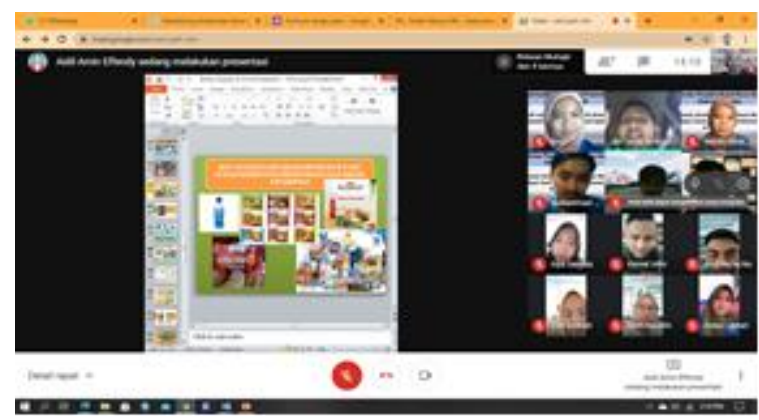

Gambar 1. Penyampaian materi oleh tim PKM

Kegiatan pada gambar diatas yaitu penyampaian materi oleh tim PKM kepada anggota Karang Taruna Dharma Temaja.

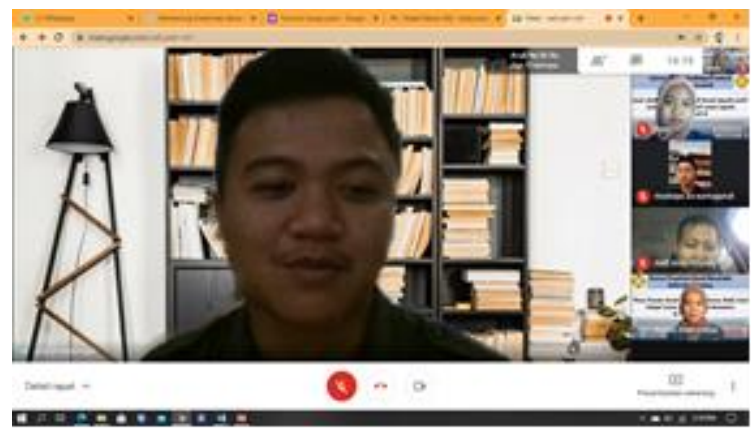

Gambar 2. Sesi Diskusi dan Tanya Jawab

Adapun gambar diatas yaitu diskusi dan tanya jawab antara peserta kepada tim PKM, kemudian TIM PKM yang merupakan mahasiswa - mahasiswa Universitas Pamulang menanggapi dan menjawab pertanyaan yang diajukan oleh para peserta

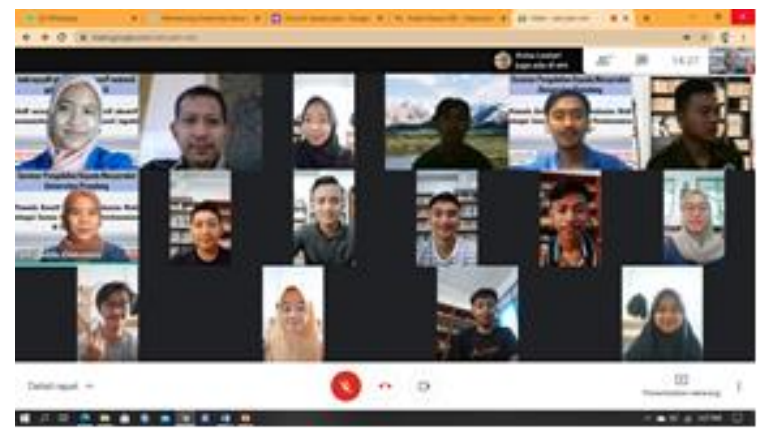

Gambar 3. Sesi Foto Bersama

Kegiatan pada gambar diatas yaitu foto bersama antara tim PKM, dosen 
pembimbing, dan anggota Karang Taruna Dharma Temaja Sumurugul

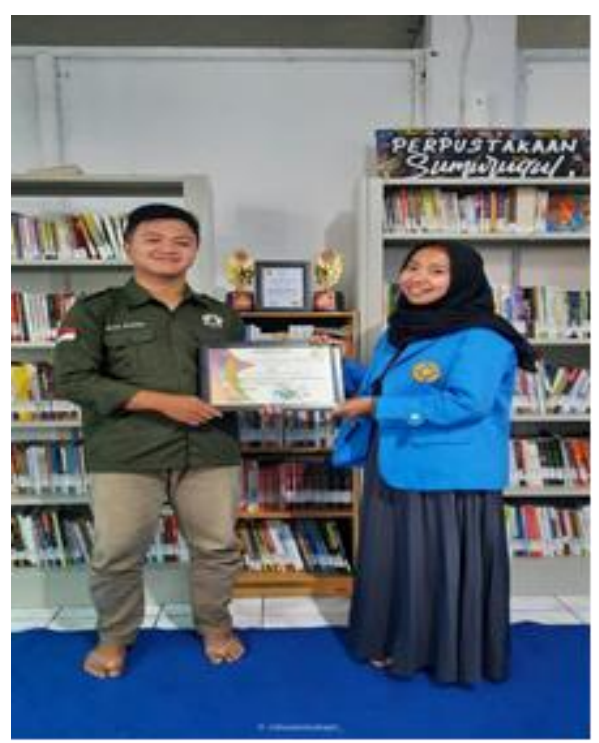

Gambar 4. Penyerahan sertifikat kepada Karang Taruna Dharma Temaja Sumurugul

Gambar diatas adalah penyerahan sertifikat yang diberikan kepada Ketua Karang Taruna Dharma Temaja oleh perwakilan tim PKM Mahasiswa Prodi Manajemen Universitas Pamulang.

\section{PENUTUP}

Kesimpulan

Hasil dari Pelaksanaan kegiatan PKM oleh mahasiswa - mahasiswa Program Studi Manajemen Universitas Pamulang dapat membuahkan hasil yang positif terlihat dari antusias dan bersemangat dalam mengikuti seluruh rangkaian kegiatan acara dari mulai pemberian materi, ice breaking, diskusi dan tanya jawab. Dari pelaksanaan kegiatan Pengabdian Kepada Masyarakat (PKM) Mahasiswa Prodi Manajemen Universitas Pamulang yang diselenggarakan melalui Webinar "Google Meet” dengan Mitra Karang Taruna Dharma Temaja Sumurugul, telah mendorong susana kebersamaan dan semangat untuk memperbaiki perekonomian desa melalui pemanfaatan media sosial dan kreatifitas.

\section{Saran}

Saran kami bagi Karang Taruna Dharma Temaja Sumurugul adalah generasi muda yang tergabung dalam organisasi ini memiliki semangat untuk memperbaiki perekonomian desa Sumurugul di masa pandemi covid 19 melalui peran pemuda kreatif dalam pemanfaatan media sosial.

\section{DAFTAR PUSTAKA}

Ajimat, A., Sunarsi, D., \& Sidiq, F. (2020). Berwirausaha Memanfaatkan Media Sosial Pada Daerah Sepatan. ADI Pengabdian Kepada Masyarakat, 1(1), 69-76.

Erlangga, H. (2020). The Challenges of Organizational Communication in the Digital Era. Solid State Technology, 63(4), 1240-1246.

Kaplan, Andreas M.; Michael Haenlein (2010) "Users of the world, unite! The challenges and opportunities of Social Media". Business Horizons 53(1): 5968.

Gamble, Teri and Michael. Communication works. Seventh edition.

Nimda (2012-02-29). "Apa itu Sosial Media". Universitas Pasundan Bandung. Diakses tanggal 2020-11-11.

Kompas (16 April 2021). Sources URL https://www.kompas.com/tren/read/ 2020/08/11/102500165/pandemicovid-19-apa-saja-dampak-padasektor-ketenagakerjaan-indonesia?page $=$ all.

Sunarsi, D. (2020). The Influence of Supply Chain Strategy on Employee Performance on Small and Medium Business in Beringharjo Market, Yogyakarta- Indonesia. International Journal of Supply Chain Management. Vol. 9, No. 5

Tekno Kompas (16 April 2021). Sources URL https://www.tekno.kompas.com/read /2021/02/24/08050027/risetungkap-lebih-dari-separuh-pendudukindonesia-melek-media-sosial.

"5 Alasan Memilih Promosi Melalui Sosial Media". IDCloudHost. 2019-02-27. Diakses tanggal 2020-06-16.

"Memaksimalkan Media Sosial untuk Bisnis Online". Niagahoster Blog (dalam bahasa Inggris). 2018-04-11. Diakses tanggal 2019-12-13. 